\title{
DETERMINAN KETIMPANGAN CAPAIAN PENDIDIKAN DI INDONESIA TAHUN 2017
}

\author{
(Determinant of Inequalities in Education Achievement in Indonesia in 2017)
}

\author{
Akbar Mubarak Amin¹, Rizka Nuralifah Cantika Putri Asani², \\ Christensenia R. J. Wattimena ${ }^{3}$, Aisyah Fitri Yuniasih4 \\ ${ }^{1}$ Politeknik Statistika STIS \\ ${ }^{2}$ Politeknik Statistika STIS \\ 3Politeknik Statistika STIS \\ ${ }^{4}$ Politeknik Statistika STIS \\ Jalan Otto Iskandardinata No.64C, Bidara Cina, Kecamatan Jatinegara, Kota Jakarta Timur, \\ Daerah Khusus Ibukota Jakarta 13330 \\ E-mail: 16.8985@stis.ac.id
}

\begin{abstract}
ABSTRAK
Indonesia sebagai negara dengan jumlah penduduk terbesar keempat di dunia dan pertama di ASEAN pada tahun 2017 seharusnya mampu memaksimalkan potensi sumber daya manusia yang ada. Sayangnya, hal tersebut belum dapat tercapai terlihat dari IPM Indonesia yang hanya menempati urutan keenam di ASEAN dan Rata-rata Lama Sekolah (RLS) penduduk Indonesia yang belum mencapai target wajib belajar sembilan tahun. RLS antarprovinsi di Indonesia yang berbeda menunjukkan terjadinya ketimpangan pendidikan, dimana DKI Jakarta merupakan provinsi dengan RLS tertinggi yaitu sebesar 1,65 kali lebih tinggi dari Papua yang merupakan provinsi dengan RLS terendah. Penelitian ini bertujuan untuk mengetahui gambaran ketimpangan capaian pendidikan yang diukur dengan Koefisien Gini Pendidikan (KGP) di Indonesia dan faktor-faktor yang memengaruhi KGP tahun 2017 dengan metode regresi linear berganda. Hasil penelitian menunjukkan ketimpangan pendidikan di Indonesia pada tahun 2017 berada pada kategori ketimpangan rendah. Jika dilihat dari klasifikasi wilayah, daerah perkotaan memiliki nilai KGP lebih rendah dibandingkan daerah perdesaan. Sedangkan menurut jenis kelamin, KGP Laki-laki lebih rendah dibandingkan perempuan. Selain itu, anggaran pendidikan dan persentase penduduk berusia 15 tahun ke atas yang melek huruf atau AMH berpengaruh negatif terhadap ketimpangan pendidikan di Indonesia tahun 2017.
\end{abstract}

Kata kunci: Ketimpangan pendidikan, Anggaran pendidikan, Angka melek huruf, Regresi linear berganda

\begin{abstract}
Indonesia as the fourth most populous country in the world and the first in ASEAN in 2017 should be able to maximize the potential of existing human resources. Unfortunately, this has not been achieved yet. It can be seen from Indonesia's HDI which ranks only sixth in ASEAN and the average length of school (RLS) of Indonesia's population who have not reached the nine-year compulsory education target. Different RLS between provinces in Indonesia shows the occurrence of educational inequality, where DKI Jakarta is the province with the highest RLS, which is 1.65 times higher than Papua, which is the province with the lowest $R L S$. This study aims to determine the description of educational achievement inequality as measured by the Education Gini Coefficient (KGP) in Indonesia and the factors that influence KGP in 2017 with multiple linear regression methods. The results showed that inequality in education in Indonesia in 2017 was in the category of low inequality. When viewed from the regional classification, urban areas have a lower KGP value than rural areas. Meanwhile, according to sex, KGP for men is lower than for women. In addition, the education budget and the percentage of the population aged 15 years and over who are literate or AMH negatively affects education inequality in Indonesia in 2017.
\end{abstract}

Keywords: education inequality, education expenditure, literacy rate, multiple linear regression

\section{PENDAHULUAN}

Tahun 2017 Indonesia adalah negara dengan jumlah penduduk terbesar menempati urutan pertama di ASEAN (World Bank, 2017). Indonesia seharusnya dapat memaksimalkan sumber daya 
manusia yang ada untuk pembangunan nasional yang berkelanjutan, sayangnya hal itu belum dapat tercapai. United Nation Development Programme mencatat Indeks Pembangunan Manusia (IPM) Indonesia pada tahun 2017 sebesar 69,4 dan menempati urutan keenam di ASEAN. Hal ini berbeda jauh dengan negara tetangga seperti Malaysia yang menempati urutan ketiga dengan IPM 80,2, dan Singapura yang menempati urutan pertama untuk negara anggota ASEAN dengan IPM 93,2.

Salah satu manfaat IPM adalah untuk mengukur keberhasilan membangun kualitas hidup manusia. Komponen yang digunakan untuk mengukur IPM ialah pendapatan, kesehatan dan pendidikan (BPS, 2017). Hidayat (2014) mengatakan bahwa sektor pendidikan menjadi sangat penting karena pendidikan memiliki dampak yang besar terhadap peningkatan kualitas sumber daya manusia. Hal ini sejalan dengan teori human capital (Schultz, 1961) yang menyatakan bahwa peningkatan pendidikan akan berdampak pada peningkatan produktivitas sehingga akan meningkatkan pendapatan. Keterkaitan antara pendidikan dan kesehatan juga dikemukakan oleh Todaro dan Smith (2011) bahwa semakin tinggi pendidikan seseorang, maka kesadaran akan kesehatan juga semakin baik.

Pendidikan tertuang dalam Sustainable Development Goals (SDGs) yaitu menjamin kualitas pendidikan yang insklusif dan merata serta meningkatkan kesempatan belajar sepanjang hayat untuk semua. Pentingnya pendidikan juga tertuang dalam pembukaan UUD 1945 dan menjadi salah satu cita-cita nasional yaitu mencerdaskan kehidupan bangsa. Oleh karena itu, pemerintah juga mengupayakan berbagai program dalam meningkatkan pendidikan salah satunya program wajib belajar 9 tahun. Salah satu indikator yang digunakan untuk mengukur capaian pendidikan masyarakat adalah Rata-rata Lama Sekolah (RLS). RLS merupakan banyaknya jumlah tahun yang dihabiskan oleh penduduk berusia 15 tahun ke atas untuk menempuh seluruh jenjang pendidikan yang pernah dijalani (BPS, 2014)

RLS Indonesia pada tahun 2017 adalah 8,46 tahun. Angka tersebut menunjukkan bahwa wajib belajar 9 tahun belum tercapai secara nasional. Jika dilihat berdasarkan provinsi, terdapat provinsi yang memiliki RLS di atas dan di bawah RLS Indonesia. Gambar 1 menunjukkan bahwa hanya terdapat 11 Provinsi atau 32,35 persen yang memiliki RLS di atas 9 tahun, dan sebanyak 23 Provinsi atau 67,65 persen lainnya masih memiliki RLS di bawah 9 tahun. Provinsi DKI Jakarta merupakan provinsi dengan RLS tertinggi yaitu 10,84 tahun. Artinya penduduk di Provinsi DKI Jakarta rata-rata mengenyam pendidikan hingga kelas 1 sampai 2 SMA. Sedangkan Provinsi Papua merupakan provinsi dengan RLS terendah yaitu 6,56 tahun. Artinya rata-rata penduduk di provinsi Papua mengenyam pendidikan hanya sampai kelas 6 SD hingga kelas 1 SMP. Perbedaan ini dapat mengisyaratkan adanya ketimpangan capaian pendidikan. Atau dengan kata lain RLS Provinsi DKI Jakarta memiliki RLS 1,65 kali lebih besar dari RLS Provinsi Papua.

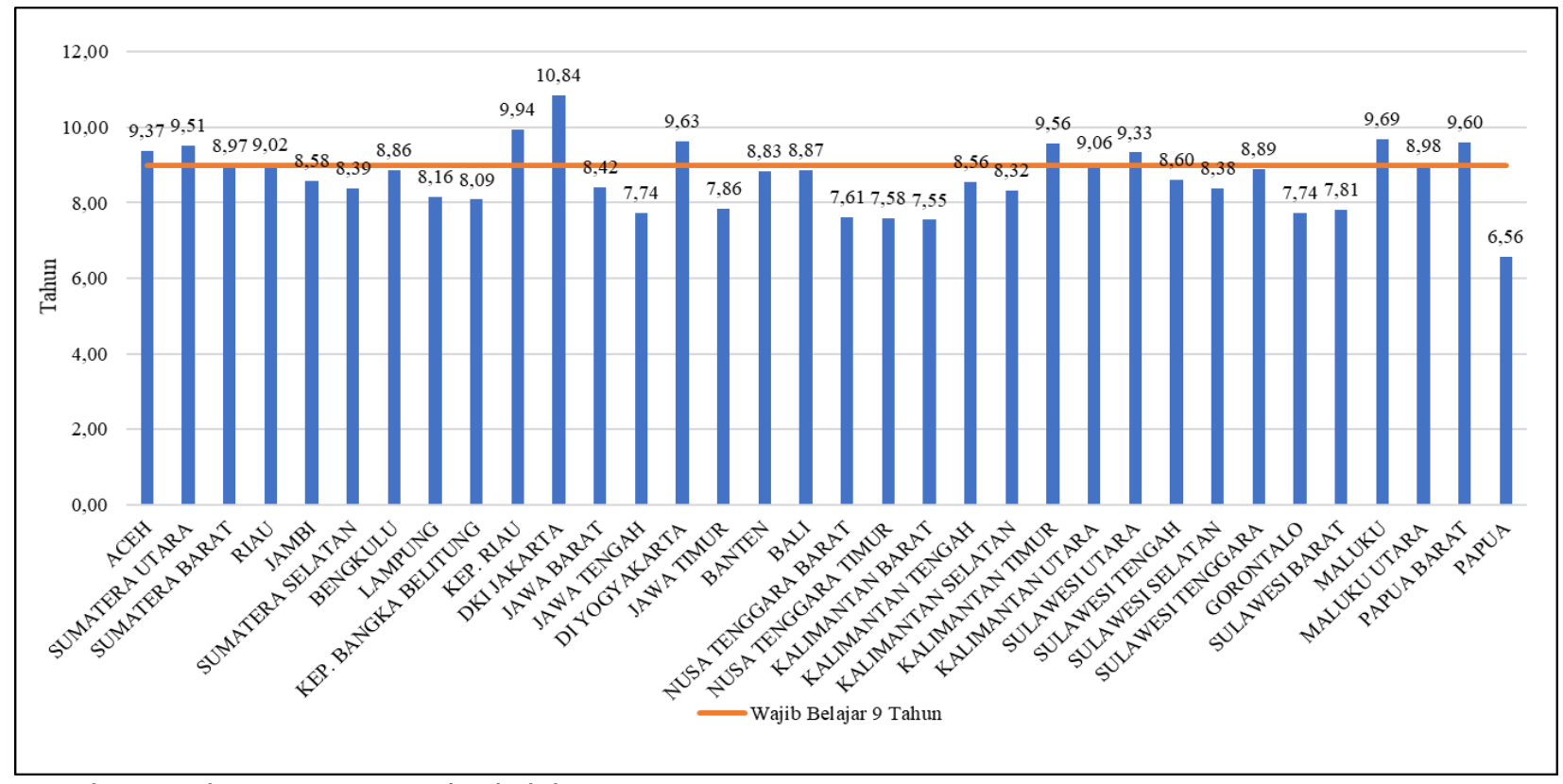

Sumber: Badan Pusat Statistik, diolah

Gambar 1. RLS Penduduk Usia 15 tahun keatas berdasarkan Provinsi di Indonesia tahun 2017 
Todaro dan Smith (2011) mengungkapkan bahwa penyediaan fasilitas pendidikan dibatasi oleh tingkat pengeluaran pemerintah. Semakin tinggi anggaran pemerintah bidang pendidikan akan meningkatkan fasilitas dan akses serta kualitas pendidikan sehingga akan meningkatkan pendidikan. Pemerintah Indonesia menganggarkan 20 persen Anggaran Pemerintah Belanja Negara (APBN) untuk biaya pendidikan. Persentase penduduk usia 15 tahun ke atas yang melek huruf atau dikenal dengan Angka Melek Huruf (AMH), menggambarkan kondisi yang terjadi di masyarakat berupa kemampuan masyarakat untuk membaca dan menulis huruf latin serta huruf lainnya (BPS, 2012). Menurut data BPS dari tahun 2008-2017 AMH penduduk Indonesia selalu mengalami peningkatan, hal ini menjadi penting bagi pendidikan di Indonesia karena tingginya AMH menunjukkan kesadaran masyarakat tentang pentingnya pendidikan semakin baik karena kemampuan membaca dan menulis masyarakat meningkat. Selain itu, penelitian yang dilakukan oleh Rondong (2009) juga menunjukkan bahwa AMH berpengaruh signifikan dalam meningkatkan pertisipasi sekolah pada jenjang menengah pertama.

Sebelumnya, Rahayu (2005) meneliti tentang Ketimpangan Pendidikan di Indonesia tahun 1975 sampai tahun 2000 menggunakan analisis data panel, diperoleh hasil bahwa ketimpangan pendidikan selama kurun waktu 25 tahun penelitian menunjukkan kebanyakan provinsi di Indonesia cenderung menurun kecuali Provinsi Papua yang mengalami kenaikan. Rahayu menemukan PDB berpengaruh signifikan sementara gender gap tidak berpengaruh terhadap ketimpangan pendidikan di Indonesia.

Digdowiseiso (2010) juga melakukan penelitian tentang ketimpangan pendidikan di Indonesia tahun 1999-2005. Hasil penelitian menunjukkan bahwa terjadi penurunan gini yang cukup signifikan di Indonesia selama kurun waktu penelitian. Digdowiseiso menemukan RLS memiliki hubungan negatif dan tingkat buta huruf menurut jenis kelamin memiliki hubungan positif dengan KGP di Indonesia.

Gambar 1 memperlihatkan adanya perbedaan RLS antar provinsi di Indonesia yang cukup signifikan dengan selisih provinsi yang memiliki RLS tertinggi dan terendah sebesar 3,92 tahun membuat peneliti ingin mengetahui ketimpangan pendidikan di Indonesia dan menganalisis lebih lanjut mengenai pengaruh anggaran pendidikan dan AMH terhadap Koefisien Gini Pendidikan (KGP) di Indonesia tahun 2017.

\section{METODE}

\section{Pendidikan}

Todaro dan Smith (2011) menyatakan bahwa pendidikan adalah input (masukan) bagi fungsi produksi nasional dalam perannya sebagai komponen modal manusia (human capital), yang berarti investasi produktif dalam sumber daya manusia

\section{Rata-rata Lama Sekolah (RLS)}

Rata-rata jumlah tahun yang ditempuh oleh penduduk berumur 15 tahun ke atas untuk menempuh semua jenjang pendidikan yang pernah dijalani (BPS, 2014).

\section{Ketimpangan Pendidikan}

Tirtarahardja \& La Sulo (2005) menyatakan bahwa ketimpangan pendidikan adalah persoalan bagaimana sistem pendidikan dapat menyediakan kesempatan yang seluas-luasnya kepada seluruh warga negara untuk memperoleh pendidikan. Ketimpangan pendidikan diukur dengan Koefisien Gini Pendidikan (KGP)

\section{Anggaran Pendidikan}

Todaro dan Smith (2011) menyatakan bahwa penyediaan tempat-tempat sekolah (fasilitas sekolah) dibatasi oleh tingkat pengeluaran pemerintah untuk sektor pendidikan. Artinya bahwa semakin besar pengeluaran pemerintah pada bidang pendidikan, maka fasilitas berupa sarana dan prasarana sekolah semakin baik.

\section{Melek Huruf}

Angka Melek Huruf (AMH) adalah proporsi penduduk kelompok umur tertentu yang dapat membaca dan menulis huruf latin atau huruf lainnya. (BPS, 2012).-provinsi 


\section{Cakupan Penelitian}

Penelitian ini mencakup seluruh wilayah Indonesia dalam hal ini cakupan berdasarkan Provinsi yaitu 34 provinsi, jenis kelamin dan klasifikasi wilayah desa/kota tahun 2017. Data yang diperlukan dalam penelitian ini yaitu RLS, KGP, anggaran pemerintah bidang pendidikan dan persentase penduduk 15 tahun keatas yang melek huruf.

\section{Metode Pengumpulan Data dan Sumber Data.}

Penelitian menggunakan raw data SUSENAS BPS tahun 2017 untuk perhitungan RLS dan KGP, data publikasi BPS tentang pesentase penduduk usia 15 tahun ke atas yang melek huruf, data Kementerian Keuangan tentang anggaran pendidikan dan data pendukung dari Kementerian Pendidikan dan Kebudayaan.

\section{Metode Analisis}

Penelitian ini menggunakan metode analisis deskriptif untuk melihat gambaran umum ketimpangan pendidikan. Sementara analisis inferensia yaitu menggunakan regresi linier berganda digunakan untuk menjelaskan pengaruh variabel anggaran pendidikan dan AMH sebagai variabel independen terhadap Koefisien Gini Pendidikan (KGP) sebagai variabel dependen. RLB dilakukan dengan cara mencari model terbaik yaitu pengujian model secara simultan menggunakan uji $F$ dan pengujian model secara parsial menggunakan uji t. Selanjutnya dari model yang terbentuk dihitung nilai residual untuk melakukan pengujian dan pengecekan asumsi klasik. Selain itu penelitian ini juga menggunakan analisis kuadran untuk mengetahui provinsi-provinsi yang menjadi prioritas dalam peningkatan anggaran pendidikan dan pengembangan program keaksaraan.

\section{HASIL DAN PEMBAHASAN}

\section{Gambaran Umum Ketimpangan Pendidikan di Indonesia Tahun 2017}

Pada tahun 2017, KGP Indonesia berada pada 0,2867 dan termasuk dalam kategori ketimpangan rendah. Hal ini merupakan hasil dari beberapa program yang dibuat pemerintah untuk meningkatkan akses serta mutu pendidikan, diantaranya peningkatan wajib belajar menjadi dua belas tahun, Program Indonesia Pintar (PIP), peningkatan dan perbaikan infrastruktur ruang kelas dan gedung sekolah serta pembangunan sekolah garis depan dan penugasan guru garis depan di daerah 3T (Terdepan, Terluar, dan Tertinggal).

Berdasarkan jenis kelamin KGP laki-laki menunjukkan angka yang lebih rendah jika dibandingkan dengan KGP perempuan yaitu sebesar 0,2626 dan perempuan sebesar 0,3142. Hal ini menunjukkan bahwa pendidikan untuk kaum laki-laki cenderung lebih merata daripada perempuan dan menunjukkan masih adanya kesenjangan antara laki-laki dan perempuan. Sesuai dengan data jumlah murid di Indonesia tahun 2017 yang menunjukkan bahwa murid laki-laki lebih banyak dibandingkan dengan perempuan, yaitu sebesar 23.301.304 murid dan perempuan sebesar 21.800 .423 murid.

Sedangkan berdasarkan klasifikasi wilayah, KGP wilayah perkotaan adalah sebesar 0,2320 sedangkan KGP wilayah perdesaan adalah sebesar 0,3227. Hal ini menunjukkan bahwa masyarakat di daerah perkotaan memiliki tingkat pendidikan yang lebih merata disbanding masyarakat daerah perkotaan. Hasil ini sesuai dengan teori yang dikemukakan oleh (Todaro dan Smith (2011) yang menyatakan bahwa pengeluaran pemerintah yang berupa investasi langsung dalam sektor ekonomi yang produktif salah satunya pengeluaran bidang pendidikan lebih besar untuk daerah perkotaan. Akibatnya, fasilitas serta akses pendidikan di daerah perkotaan juga menjadi lebih mudah sehingga meningkatkan partisipasi sekolah masyarakat di daerah perkotaan. 


\section{Gambaran Umum Ketimpangan Pendidikan menurut Provinsi di Indonesia Tahun 2017}

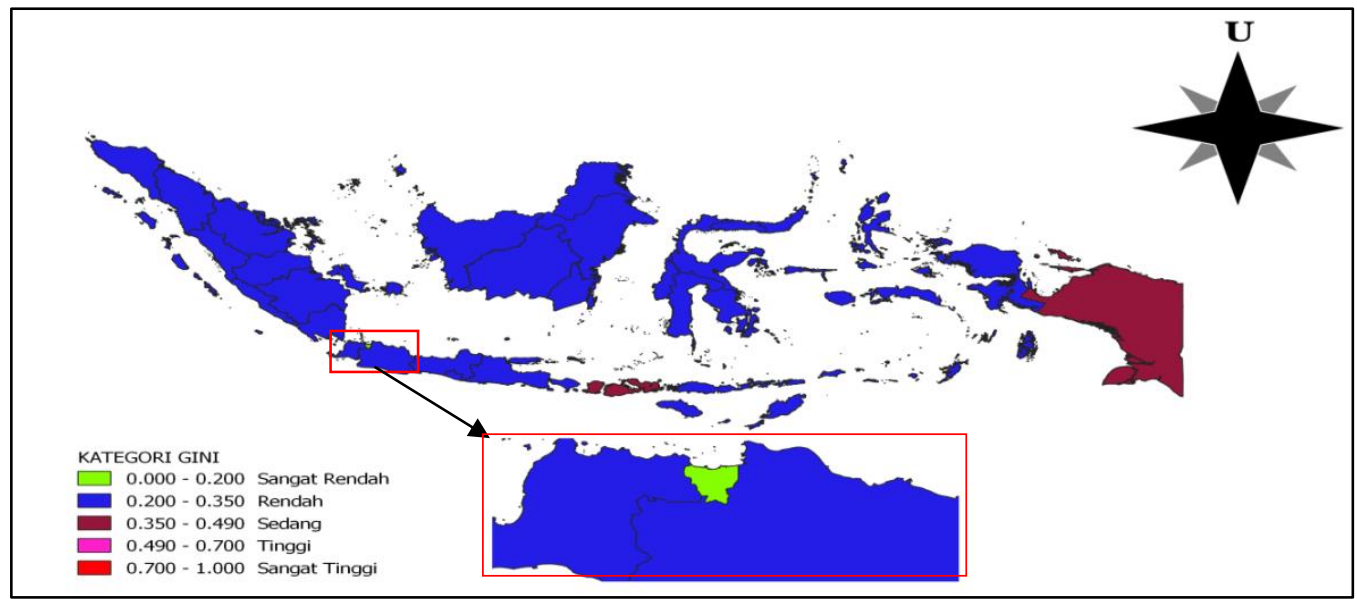

Sumber: Susenas 2017, diolah

Gambar 2. Persebaran KGP menurut provinsi di Indonesia tahun 2017

Gambar 2 menunjukkan sebaran KGP 34 provinsi di Indonesia pada tahun penelitian. Berdasarkan Gambar $\mathbf{2}$ terlihat bahwa provinsi dengan nilai KGP yang masuk pada kategori sedang di Indonesia tahun 2017 adalah Provinsi Papua dan Nusa Tenggara Barat. Jika dilihat dari letak geografis dan kawasan pembangunan menurut garis-garis besar haluan negara, daerah dengan ketimpangan pendidikan tinggi berada pada Kawasan Indonesia Timur (KTI). Sementara itu, DKI Jakarta merupakan satu-satunya provinsi di Indonesia yang masuk dalam kategori KGP sangat rendah, dan provinsi lainnya masuk dalam kategori rendah. Hal ini sesuai dengan kondisi persentase melek huruf dan anggaran pendidikan di Provinsi DKI Jakarta yang sangat tinggi.

\section{Gambaran Umum Anggaran Pendidikan di Indonesia Tahun 2017}

Anggaran pendidikan di sebagian besar provinsi di Indonesia umumnya masih rendah. Provinsi dengan anggaran pendidikan tertinggi adalah provinsi DKI Jakarta, yaitu sebesar 27 persen dari APBD. Tingginya anggaran pendidikan akan berdampak pada penyediaan berbagai fasilitas bidang pendidikan, sehingga DKI Jakarta yang memiliki anggaran cukup besar mampu meningkatkan akses terhadap pendidikan di daerahnya. Hal ini sesuai dengan kondisi KGP Jakarta yang merupakan KGP terendah di Indonesia.

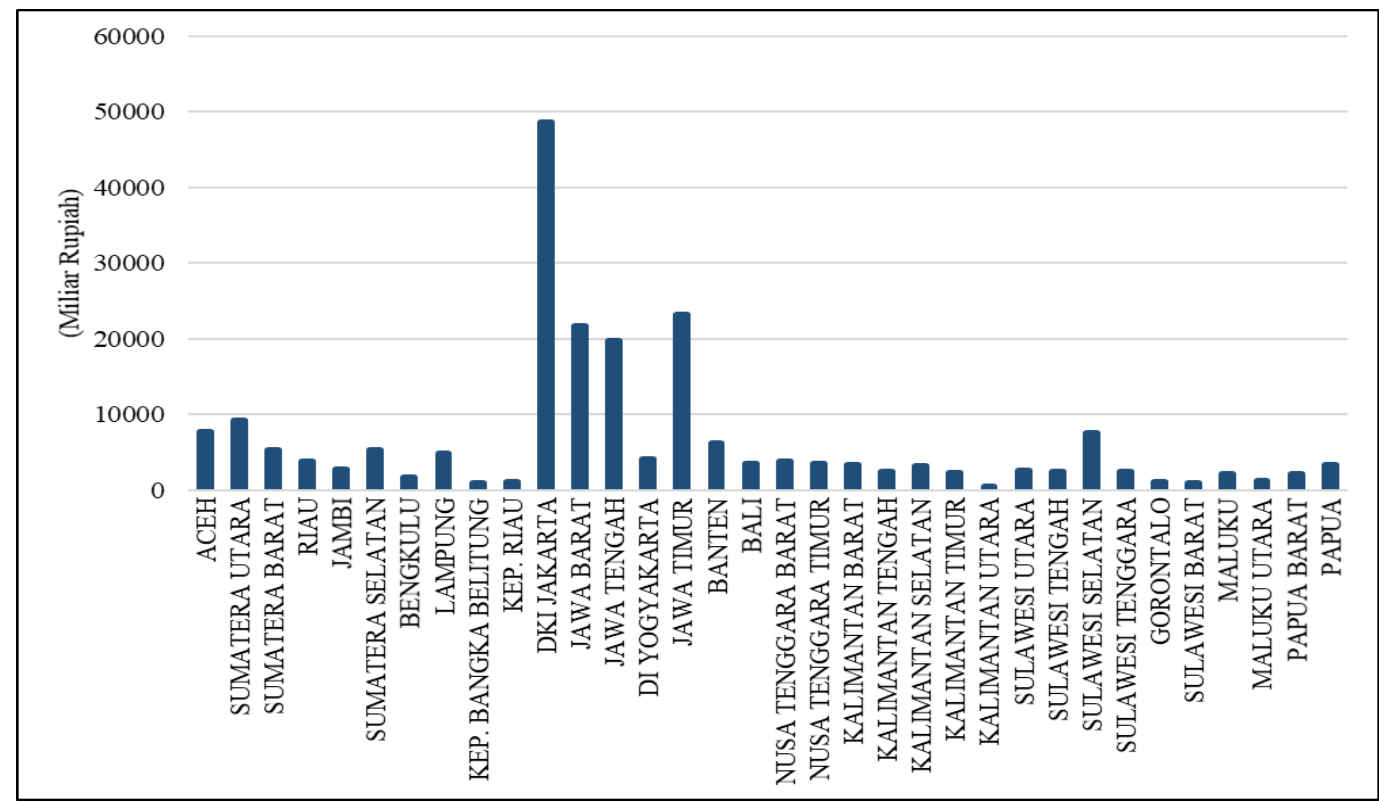

Sumber: Kemendikbud RI, diolah

Gambar 3. Anggaran pendidikan berdasarkan provinsi di Indonesia tahun 2017 


\section{Gambaran Umum Persentase Penduduk Berusia 15 Tahun keatas yang Melek Huruf (AMH) di Indonesia Tahun 2017}

Pada umumnya kondisi angka melek huruf di Indonesia sudah cukup baik karena hampir seluruh provinsi di Indonesia memiliki angka melek huruf di atas 90 persen, kecuali pada provinsi Papua dan Nusa Tenggara Barat. Sementara itu, Provinsi DKI Jakarta merupakan provinsi dengan angka melek huruf tertinggi yaitu mencapai 99,68 persen.

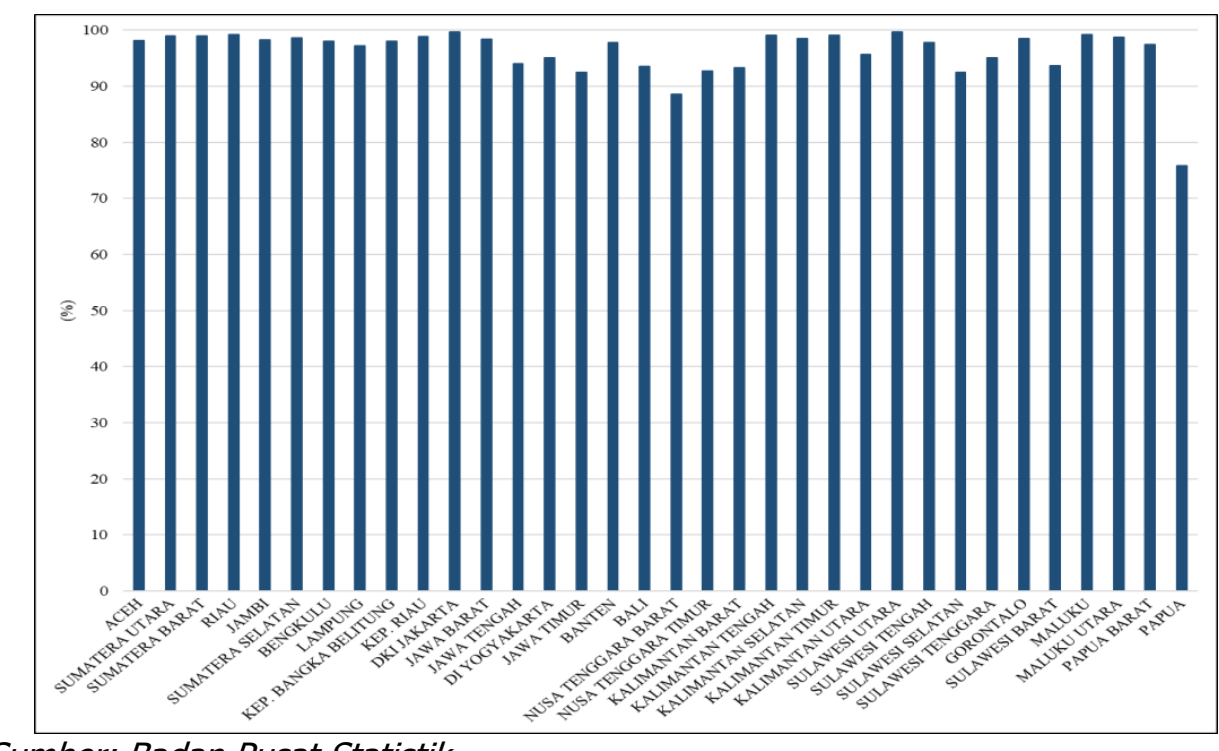

Sumber: Badan Pusat Statistik

Gambar 4. Persentase penduduk berusia 15 tahun keatas yang melek huruf berdasarkan provinsi di Indonesia tahun 2017

\section{Pengaruh Anggaran Pendidikan dan Angka Melek Huruf terhadap KGP di Indonesia Tahun 2017}

Untuk mengetahui pengaruh anggaran pendidikan dan AMH terhadap KGP di Indonesia tahun 2017, maka dilakukan analisis inferensia menggunakan metode estimasi Regresi Linier Berganda (RLB) Ordinary Least Square (OLS). Hasil perhitungan diperoleh model sebagai berikut.

$\hat{Y}=1,069-9,206 \times 10^{-7} X_{1}-0,008 X_{2}$

dengan $X_{1}$ adalah anggaran pendidikan dan $X_{2}$ adalah AMH.

Berdasarkan model dilakukan pengujian signifikansi variabel dengan menggunakan uji $F$ (simultan) dan uji t (parsial) diperoleh kesimpulan bahwa anggaran pendidikan dan AMH negatif signifikan memengaruhi KGP di Indonesia tahun 2017 dengan koefsien determinasi sebesar 79,8 persen. Artinya model yang diperoleh dapat menjelaskan keragaman KGP sebesar 79,8 persen dari variabel anggaran pendidikan dan AMH sedangkan sisanya dijelaskan oleh variabel lain yang tidak dimasukkan ke dalam model.

Pengujian asumsi klasik dilakukan untuk melihat apakah model layak digunakan. Dari pengujian empat asumsi klasik yaitu normalitas, heteroskedastisitas, multikolinearitas dan autokorelasi didapatkan hasil bahwa model yang terbentuk dapat digunakan karena memenuhi asumsi-asumi dalam OLS.

Setelah melalui beberapa tahapan, maka didapatkan bahwa model $\hat{Y}=1,069-9,206 \times$ $10^{-7} X_{1}-0,008 X_{2}$ merupakan model yang dapat menjelaskan keragaman variasi ketimpangan pendidikan yang diukur dengan KGP. Intersep pada model menunjukkan besarnya KGP Indonesia jika nilai variabel anggaran pendidikan dan AMH konstan.

\section{Anggaran Pendidikan terhadap KGP}

Dari model yang dibentuk, anggaran pendidikan signifikan memengaruhi KGP dengan nilai koefisien regresi sebesar -9,206 $\times 10^{-7}$. Artinya bahwa setiap penambahan 1 Miliyar Rupiah anggaran pendidikan maka akan menurunkan gini pendidikan sebesar 9,206 × 10-7 atau dengan kata lain setiap penambahan 1 Triliun Rupiah anggaran pendidikan maka akan menurunkan gini pendidikan sebesar 0,0009206 dengan asumsi AMH konstan. Hal ini sesuai dengan Todaro dan Smith (2011) yang 
menyatakan bahwa semakin besar anggaran pemerintah bidang pendidikan, maka penyediaan fasilitas pendidikan juga akan semakin baik, sehingga akan menurunkan ketimpangan pendidikan.

\section{AMH terhadap KGP}

Dari model regresi yang didapat, AMH berpengaruh signifikan terhadap KGP dengan koefisien regresi sebesar 0,008. Artinya setiap penambahan 1 persen penduduk berusia 15 tahun ke atas yang melek huruf akan menurunkan gini pendidikan sebesar 0,008 dengan asumsi alokasi anggaran pendidikan konstan. Sesuai dengan BPS yang menyatakan bahwa Angka Melek Huruf (AMH) dapat menggambarkan kemampuan membaca dan menulis masyarakat. Semakin tinggi angka melek huruf, maka semakin tinggi kemampuan masyarakat untuk membaca, menulis dan menyerap informasi sehingga akan menurunkan ketimpangan pendidikan. Hasil ini juga sejalan dengan penelitian Rondong (2009), yang menyatakan bahwa faktor pendidikan orang dewasa yang diukur dengan angka melek huruf laki-laki secara signifikan memengaruhi partisipasi sekolah jenjang SMP/MTS.

\section{Plot Anggaran Pendidikan dan KGP di Indonesia Tahun 2017}

Untuk menganalisis lebih lanjut mengenai provinsi yang perlu meningkatkan anggaran pendidikan guna menurunkan KGP, maka dilakukan analisis kuadran.

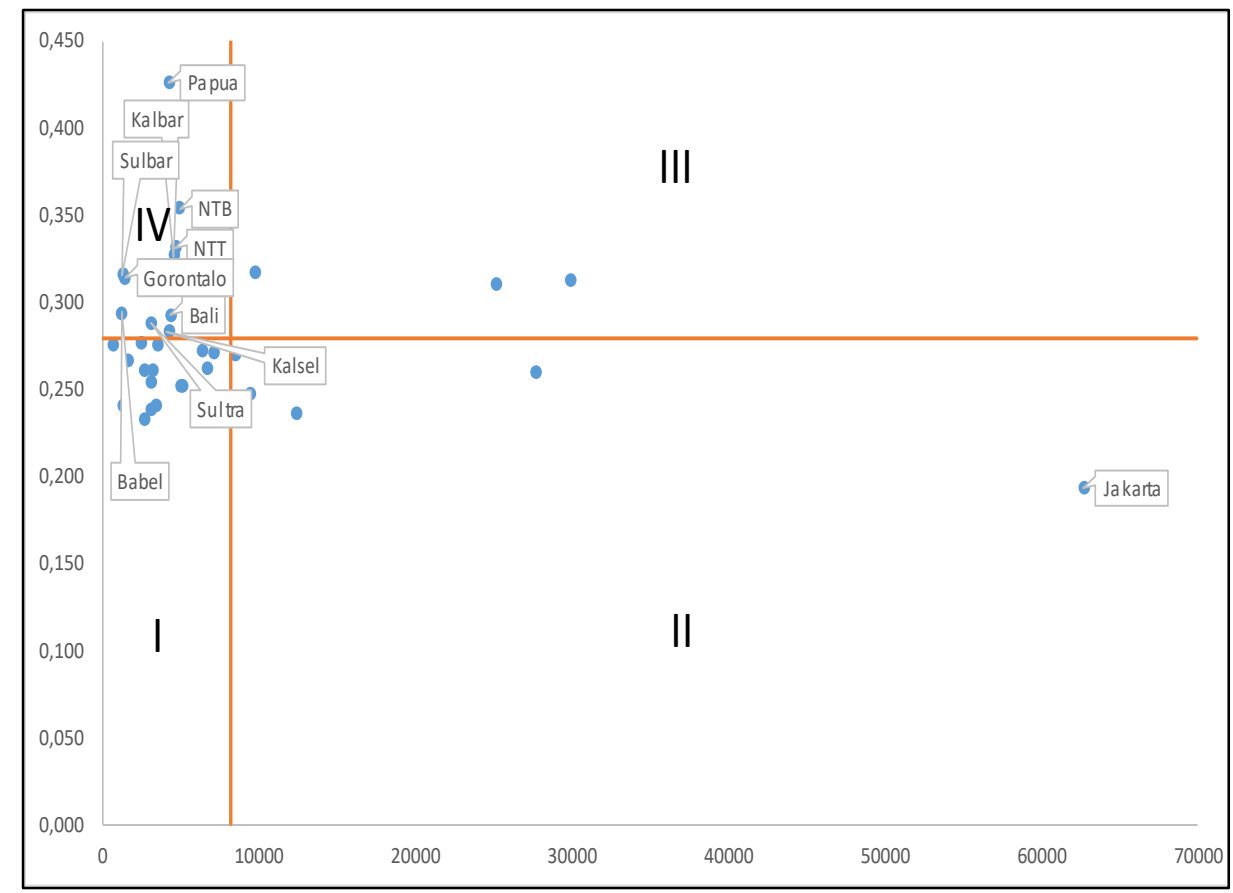

Sumber: Badan Pusat Statistik, diolah

Gambar 5. Plot antara alokasi anggaran pemerintah bidang pendidikan dan KGP tahun 2017

Berdasarkan Gambar 5, provinsi yang perlu diperhatikan adalah provinsi yang berada pada kuadran IV, yaitu provinsi dengan KGP melebihi KGP nasional dan anggaran pendidikan provinsi terkait kurang dari rata-rata anggaran pendidikan nasional. Provinsi tersebut adalah provinsi Bangka Belitung, Kalimantan Barat, Kalimantan Selatan, Gorontalo, Sulawesi Barat, Sulawesi Tenggara, Bali, NTB, NTT, dan Papua.

\section{Plot Angka Melek Huruf dan KGP di Indonesia Tahun 2017}

Untuk menganalisis lebih lanjut mengenai provinsi yang perlu meningkatkan angka melek huruf guna menurunkan KGP, maka dilakukan analisis kuadran. 


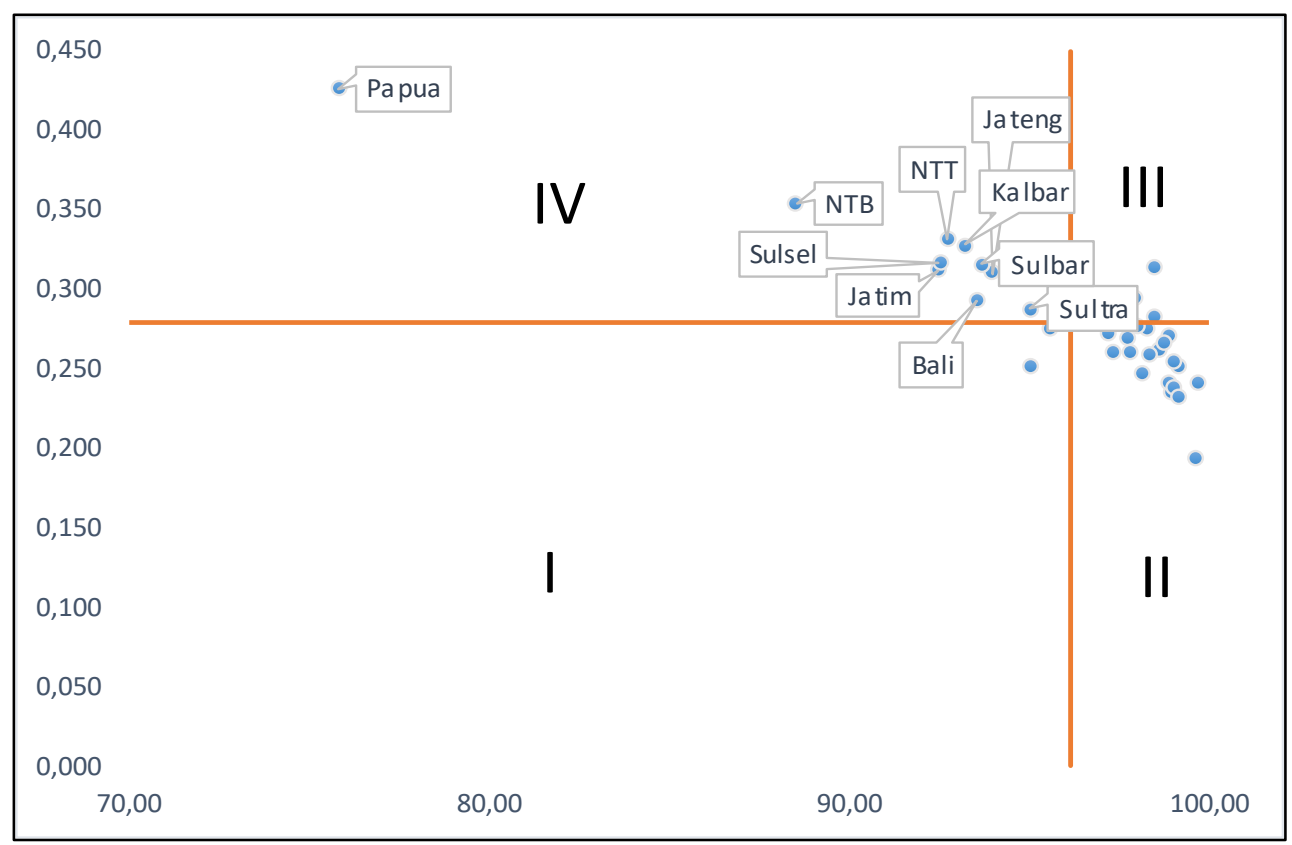

Sumber: Badan Pusat Statistik, diolah

Gambar 6. Plot antara persentase penduduk berusia 15 tahun ke atas yang melek huruf dan KGP 2017

Berdasarkan Gambar 6, provinsi yang perlu diperhatikan adalah provinsi yang berada pada kuadran IV, yaitu provinsi dengan KGP melebihi KGP nasional dan angka melek huruf provinsi terkait kurang dari angka melek huruf nasional. Provinsi tersebut adalah provinsi Jawa Tengah, Jawa Timur, Kalimantan Barat, Sulawesi Barat, Sulawesi Selatan, Sulawesi Tenggara, Bali, NTB, NTT, dan Papua.

\section{KESIMPULAN}

Berdasarkan hasil dan pembahasan maka dapat dibuat kesimpulan sebagai yaitu ketimpangan pendidikan di Indonesia pada 2017 sebesar 0,2867 dan berada pada kategori . Ketimpangan menurut jenis kelamin pada tahun 2017 untuk perempuan lebih tinggi jika dibandingkan ketimpangan pada laki-laki. Kemudian, ketimpangan pendidikan menurut klasifikasi wilayah desa/kota tahun 2017 untuk daerah pedesaan lebih tinggi jika dibandingkan dengan daerah perkotaan. Variabel yang signifikan memengaruhi ketimpangan pendidikan di Indonesia adalah anggaran pendidikan dan angka melek huruf. Kedua variabel mampu menjelaskan variasi ketimpangan pendidikan di Indonesia pada tahun 2017 sebesar 81 persen.

\section{DAFTAR PUSTAKA}

World Bank. (2017). Indonesia's Rising Divide. Diakses pada 4 Januari 2019 melalui http://documents.worldbank.org/curated/en/267671467991932516 I /pdf/106070-WP-PUBLICIndonesias-Rising-Divide-English.pdf .

BPS. (2012). Statistik Pendidikan 2012 Survei Sosial Ekonomi Nasional. Jakarta: Badan Pusat Statistik.

BPS. (2014). Statistik Pendidikan 2014. Jakarta: Badan Pusat Statistik.

BPS. (2017). Potret Pendidikan di Indonesia Statistik Pendidikan 2017. Jakarta: Badan Pusat Statistik.

Digdowiseiso, K. (2010). Measuring Gini Coefficient of Education: the Indonesian Cases. Diakses pada tanggal 6 November 2018 melalui https://mpra.ub.unimuenchen.de/19865/1/Measuring Gini Coefficient of Education.pdf.

Hidayat, M. H. (2014). Pendidikan dan Kesehatan dalam Pembangunan Ekonomi. Diakses pada 15 Mei 2019 melalui

https://www.academia.edu/16715231/

Pendidikan dan Kesehatan Dalam Pembangunan Ekonomi.

Rahayu, A. (2005). Ketimpangan Pendidikan di Indonesia. Diakses pada tanggal 6 November 2018 melalui http://journal.umy.ac.id/index.php/esp/article/ download/2147/2074.

Rondong, F. (2009). Faktor-faktor yang mempengaruhi Partisipasi Sekolah Pada Jenjang Pendidikan Dasar: SD/MI dan SMP/MTS di Indonesia. Diakses pada 6 Juni 2019 melalui http://lib.ui.ac.id/file?file=pdf/abstrak-133149.pdf

Schultz, T. W. (1961). Investment in Human Capital. Diakses pada 15 Mei 2019 melalui https://www.jstro.org/stable/1818907?seq=1\#page scan tab contents 
Tirtarahardja, U. \& La Sulo, S. L. (2005). Pengantar Pendidikan (Edisi Revisi). Jakarta: PT Asdi Mahasatya. Todaro, M. P., \& Smith, S. C. (2011). Pembangunan Ekonomi Edisi kesebelas Jilid 1. . Jakarta: Erlangga. 